IZA DP No. 5880

Evolution of the Industrial Wage Structure in China Since 1980

O Hyun Kwon

Belton M Fleisher

Quheng Deng

July 2011 


\title{
Evolution of the Industrial Wage Structure in China Since 1980
}

\author{
O Hyun Kwon \\ Peking University \\ Belton M Fleisher \\ Ohio State University \\ and IZA \\ Quheng Deng \\ Chinese Academy of Social Sciences \\ Discussion Paper No. 5880 \\ July 2011 \\ IZA \\ P.O. Box 7240 \\ 53072 Bonn \\ Germany \\ Phone: +49-228-3894-0 \\ Fax: +49-228-3894-180 \\ E-mail: iza@iza.org
}

\begin{abstract}
Any opinions expressed here are those of the author(s) and not those of IZA. Research published in this series may include views on policy, but the institute itself takes no institutional policy positions.

The Institute for the Study of Labor (IZA) in Bonn is a local and virtual international research center and a place of communication between science, politics and business. IZA is an independent nonprofit organization supported by Deutsche Post Foundation. The center is associated with the University of Bonn and offers a stimulating research environment through its international network, workshops and conferences, data service, project support, research visits and doctoral program. IZA engages in (i) original and internationally competitive research in all fields of labor economics, (ii) development of policy concepts, and (iii) dissemination of research results and concepts to the interested public.
\end{abstract}

IZA Discussion Papers often represent preliminary work and are circulated to encourage discussion. Citation of such a paper should account for its provisional character. A revised version may be available directly from the author. 


\section{ABSTRACT}

\section{Evolution of the Industrial Wage Structure in China Since $1980^{*}$}

Industry mean wages in China have exhibited sharply increased dispersion since the early 1990s. The upward trend in differences of average wages among major industry groups parallels increases in wage and income inequality not only between rural and urban sectors but within the urban economy as well. Research on the trend has focused on (1) how market forces have led to a better match between worker pay and worker skills; on (2a) how the growing share of employment in the private sector has "caused" growing wage inequality; and (2b) how residual government control in a few industrial sectors has contributed to wage inequality due monopoly rent sharing. We show that the industrial wage dispersion in China has evolved to match long-recognized international patterns of industrial wage dispersion and that an increasing proportion of industrial wage dispersion can be explained as returns to observed worker characteristics.

JEL Classification: J31, D22, D33, L16, 053

Keywords: industry-wage structure, inequality, China

Corresponding author:

Belton M Fleisher

Department of Economics

Ohio State University

410 Arps Hall

1945 N. High Street

Columbus, $\mathrm{OH} 43210$

USA

E-mail: fleisher@econ.ohio-state.edu

\footnotetext{
* We have benefitted from comments made during presentations of this paper at the Chinese Economists Society Beijing conference in June, 2011 and from presentations at the Chinese Academy of Social Sciences and to the School of Economics and Business at Beijing Normal University. We are particularly grateful to Juan Yang for her advice and to Simon Change, Cai Fang and to Li Shi for their suggestions.
} 


\section{Introduction}

Wagedifferentials under planning in China, Eastern Europe, and the Soviet Union were severely compressed relative to the norm in market economies. In their post-planning transition to wage structures determined by market forces, all of these formerly planned economies have experienced increased dispersion of wages and incomes. This growing inequality is observed in industrial, occupational, skill, schooling, and regional dimensions. We focus on the evolution of the industrial wage structure (IWS) in Chinafor two reasons: (i)a number of scholars and commentators question whether rising inequality in China is the result of market forces or the result of barriers to competition in industries where government retains a dominant ownership position; (ii) the IWS has received the attention of economists for more than 60 years and remains a topic with tantalizing unanswered questions today. We document that industrial wage dispersion in China, while very low in 1978, now ranks high among major industrial economies. However, the pattern of wage dispersion across industries is highly correlated across countries, including China. Although traditionally high-wage industries are those that tend to have highly concentrated ownership, we find that wage inequality across industries in China is higher, and has grown more, in the non-State-owned sector than it has among state-owned units (SOUs) and collectively-owned units. The hypothesis that the growing dispersion of China's IWS is the result of market forces common to the world's major market economies is not rejected by our empirical results.

The rest of this paper proceeds as follows. In section 2 we illustrate the evolution of the IWS in China since the beginning of economic reform. Section 3 contains a brief history of the literature on the IWS and presents our methodology. We present our empirical results in section 4, and section 5 concludes.

\section{The Chinese Industrial Wage Structure Since 1978.}

As stated in the Introduction, a major feature of China's IWS is the dramatic 
increase in wage dispersion over the past 30 years or more. Figure 1 showsthe coefficient of variationof mean industrial wages in China, the United States, Canada, and four major industrial economies in Europe over various time periods through 2007 or 2008. The dispersion of industrial wages in China was very low compared to most other countries until the late 1980s; it accelerated sharply between 1993 and 1995, a period of rapid increase in the proportion of workers in China's non-public employment sectors (Gustafsson and Li, 2001), probably encouraged by the policy changes associated with Deng Xiao Ping's Southern Tour in 1992. The upward trend has continued, increasing after the year 2003. In contrast to China, the IWS trends in the other countries depicted in figure 1 were quite stable. A similar stability in the industrial wage dispersion for 8 nations in the European Union over the period 1991 through 2002 is reported in Genre, Kohn, and Moferatou (2009). Similarly to the data in figure 1, Genre, Kohn, and Monferatou show that Spain (and Portugal) have the highest degree of industrial wage dispersion, while Finland, not represented in figure 1, has a much more compressed IWS, comparable to that of China prior to 1993.

A second major feature of the IWS in China is its convergence toward a stable and common international pattern of high-wage versus low-wage industries. To illustrate the stability over time of the IWS, figure 1shows that the rank correlation of industry average wages in the United States in 1978 with average wages in 2008 was 0.90. In contrast, the rank correlation of industry average wages in 1978 with 2008 is less than 0.50 , gradually rising over time, by definition, to 1.0 in 2008.Table 2 and figure 2 show the correlation of average industry wages in eight major industrialized economies in recent years with average industry wages in China between 1978 and 2008. There is a distinct upward trend in the correlation over the period, with the average correlation coefficient exceeding 0.6 in each year since 2004.

\section{Literature and Methodology}

Two major features of the lengthy literature on the IWS are the persistence of high correlation of industry wages over time and their high average correlation across countries.

In a classic paper Slichter (1950) noted that wage rates varied significantly 
across major industry categories in ways that could not readily be explained in terms of perfectly competitive labor markets and that the inter-industry structure of wages was quite stable over time, the rank correlation of mean wages between 1923 and 1946, following the Second World War being 0.88. Since then it has been shown in numerous papers that stability is not only persistent but extends to a surprising extent across industrialized economies. For example, the correlation between mean industrial wages in the United States in 1984 with mean industrial wages in China in the year 2002 is 0.9.

\section{Time-stability of the Industrial Wage Structure}

In a seminal paper, Slichter (1950) used data collected by the National Industrial Conference Board to show that the rank correlation of mean hourly earnings between 1923 and 1946 is 0.73, concluding, "The inter-industry structure of wages has considerable stability during short or moderately periods of time". In a frequently cited work, Krueger and Summers (1987) corroborate the over-time stability of the industrial wage structure. They compare the United States industrial wage structure in 1923 with that in 1984 and find the correlation of log wages to be 0.56 . Moreover they believe this to be an underestimate attributable to changes in industry definitions and sampling error. Further evidence is obtained when the wages of 9 major industries in 1900 are related to those in 1920 and 1984 . They find log wage correlations of 0.80 and 0.62 , respectively.

Later research including DIXON(1995),.... Use data from countries other than the US and respectively corroborate the finding that industrial wage structure is stable over time. Therefore, it seems that researchers in this topic has basically reached a consensus that industrial wage structure is stable across time.

\section{Similarity of Industrial Wage Structures across Developed Countries}

A major contribution of Krueger and Summers (1987) is to confirm results reported in earlier work (Lebergott, 1947, Dunlop and Rothbaum, 1955, and Papola and Bharadwaj, 1970) that the industrial wage structure is highly correlated across industrialized economies. Data for 13 countries yield correlations of industrial wages with the United States that exceed 0.8 for 8 countries and more than 0.6 for 11 countries.. More recently, Genre, Momferatou, and Mourre (2005) report that 
industrial wage averages are highly correlated across Euro Zone countries although they differ substantial in their degree of dispersion. US. There is also evidence ( Erdil and Yetkiner, 2001) that there is a significant, positive rank correlation of industrial wages between industrialized and developing economies.

\section{Puzzles and explanatory models related to the Industrial Wage Structure}

It might be argued that industrial wage differentials unexplained by observed worker characteristics mainly reflect market disequilibrium. We find it implausible that disequilbria can account for the long-term stability of the IWS within countries and its similarity across economies. Thus, understanding the IWS requires exploration of the underlying market equilibria that determine it.

Competitive explanation: Equalizing differentials. Writers at least since Slichter (1950) have offered a variety of explanations of the IWS. In general they take as a benchmark the competitive hypothesis (Reder, 1962), which in its simplest form states that equally productive workers should receive equal wages regardless of which industry employs them. The simple competitive hypothesis has always been interpreted much more richly and is perhaps expressed most eloquently in Rosen (1986), who states, “The theory of equalizing differences refers to observed wage differentials required to equalize the total monetary and nonmonetary advantages or disadvantages among work activities and among workers themselves (p. 641). It is assumed that both sides of the market (employers and employees) possess perfect information about worker and job chacteristics. As Rosen emphasizes, empirical testing of the competitive hypothsis(es) is extremely difficult, because it require matched employer-employee data with detailed information about both worker and job characteristics. Consequently, consensus on the degree to which observed wage distributions correspond to the competitive paradigm remains elusive. Testing is further complicated by the introduction asymetric information and the need to distinguish between observations of long-run equilibrium and short-term demand or supply shocks.

(i)Variation in labor characteristics. In a competitive labor market equilibrium pay would correspond to worker skill, and inter-industry variation in average wage 
levels would correspond to variation in skill levels. Any residual wage variation after skills have been accounted for would compensate employees (negatively or positively) for heterogenous working conditions such as safety, comfort, work-hours flexibility, and so on. In general, observable skills and working conditions cannot account for all of the IWS. In their 1987 paper, Krueger and Summers regress industry mean log wage rate on measures of worker skills and other characteristics (e.g. gender) and can account for about 40 per cent of observed industry wage dispersion. Moreover, the residual industry wage differentials' rank correlation with the raw differentials is about 0.9 . The extent to which the unexplained differentials reflect unobserved labor quality or reflect deviation from the competitive paradigm is unanswered.

An appealing method to control for unobserved worker characteristics is to examine the wages for workers who change jobs. However, a challenge is to account for selection bias that arises because voluntary job change should require that workers are offered higher wages or better working conditions on their new jobs than they received in their old jobs. After accounting for such bias, Krueger and Summers find that residual industrial wage differentials are not significantly reduced. They conclude that this "cast[s] doubt on explanations of industry wage differentials based on unmeasured quality”. Gibbons and Katz (1987) and Blackburn and Neumark (1988) reach a similar conclusion. However, Murphy and Topel (xxxx), using a differentCPS sample and different method of correcting for selection bias find that the industrial wage differentials for workers who change industries are only one-third of total industrial wage differentials, which suggests that two-thirds are explained by unobserved worker characteristics.

(ii) Variation in job characteristics and endogeneity. Accounting for unobserved worker characteristics is complicated by the two-way exchange of worker services for job amenities emphasized by Rosen (1986). In the competitive paradigm, the observation that seemingly similar occupations are paid more in some industries than in others (Krueger and Summers 1987, Katz and Summers 1989) must be attributable to industry-specific job amenities or working conditions. For example, mining jobs are intrinsically dangerous and often require working in dark and otherwise 
unpleasant locations. Workers who are less averse to working in dark, dangerous places are more likely to select into mining jobs in return for a lower wage premium than workers who are more averse. Consider, however, a worker who leaves a mining job for a job in another industry in return for better job amenities. If we attribute industry-specific wage residuals in a sample of industry-job changers to unobserved worker characteristics, we risk serious error and omitted variable bias to the extent that industry-specific job amenities are ignored. A further complication is that worker characteristics are tied to the individual; his/her aversion to dark places cannot in general be separated in the job market from his/her schooling, place of birth, parental education, and so on. Thus, even with perfect labor mobility, the bundling of worker characteristics may militate against equalization of returns to observed or unobserved worker characteristics across industries.

The two-sided nature of the job transaction and the likely endogeneity of many job amenities and some worker characteristics (schooling, for example) make over-time and cross-country comparisons still more complex than measuring the IWS at a point in time in a given economy. Consider, for example, the industry wage residual for mining in China compared to the United States. As is shown in our empirical results, mining is a "high-wage" industry in the United States and a "low-wage" industry in China. We conjecture that Chinese mining jobs are not intrinsically less dangerous than those in the United States. (Indeed casual reading of news reports would suggest the opposite.) Nor do we find it plausible that Chinese workers have vastly different preferences than do American miners. But tradeoffs occur at the margin on both the employer and employee sides of the wage bargain. An equilibrium outcome in which Chinese workers who face far less attractive job alternatives than those in the United States would be more inclined to accept a lower wage premium for unattractive jobs (and less likely to form labor unions) and in which employers would not find it profitable to invest in costly safety measures and other items to improve working conditions is entirely plausible. Thus, the difference between the United States and China wage gap for mining compared to other industries is consistent with identical 
worker preferences and industry production functions in the two countries, and the over-time and cross-country similarity of IWS results is remarkable indeed.

(iii.) Challenges to the Competitive Hypothesis: Efficiency Wage Hypotheses and Rent-Sharing.The persistence over time and across countries of unexplained industry-wage differentials presents a serious challenge to the competitive hypothesis under the assumption of full information. Two contending explanations involve relaxing the assumption of full information and/or the assumption of profit maximization.

High-wage industries tend to be those in which employers have a relatively high degree of market power as measured by standard concentration ratios or by firm size and this has been by some observers as evidence of monopoly rent sharing (Brown and Medoff 1985,Kwoka 1983, Mishel 1982, Dickens and Katz 1986b). Slichter (1950), Pugel (1980), and Dickens and Katz (1986b) also note that industries with high profit ratios tend to be correlated with higher wage payments. However, Krueger and Summers (1988) note that profit rates across industries tend to be insensitive to a broad range of wage variation, suggesting that higher wages lead to lower overall costs, cet. par. For example, high-wage industries tend to have lower quit rates, which means that employers can avoid additional hiring and training costs (Katz and Summers 1989, Akerlof, rose, and Yellen 1989). Krueger and Summers (1988) analyze the role of efficiency wage models in accounting for the residual IWS. They note that efficiency-wage models can explain employers' choices to pay higher wages than their employees would receive in alternative jobs as a means to avoid costs associated with monitoring and worker turnover. They observe that it is difficult to separate profit-maximization from utility-maximization motives (e.g. agency problems in large corporations (Brown and Medoff, 1985)) in empirical evaluation of the residual IWS, and they “...prefer to regard rent sharing as a species of efficiency wage theory rather than as an alternative explanation for wage differentials.” They call for future research to isolate the causes of the residuals unexplained by observed worker and job characteristics.

Another issue related to rent sharing is unionization. Unions can bargain 
successfully for higher wages in industries where rents are high, and the degree of unionization may be endogenously related to employer market power. There is evidence that industry average wage rates are positively correlated with the extent of unionization unionization rate, but Krueger and Summers (1987) find that high wage industries tend to pay high wages even before the advent of wide-scale unionization, and ... which is an evidence casting some doubt on whether correlation between industry average wage and high unionization can be interpreted as a causal relationship.

\section{Recent Research on the Industrial Wage Structure in China}

Research in the IWS in China has focused on explaining growing wage and income inequality, especially among the urban population. Chen, Lu, and Wan (2010) regress industry average wages on the "usual suspects” including worker characteristics and industry dummy variables and find that over half of the industry wage dispersion (holding constant worker characteristics) is attributable to two industries - transportation, storage, post office, and communication; and finance and insurance. Since these two industries are dominated by government-owned enterprises, they infer that government monopoly explains the recent rise in industrial wage differentials. in the two industries mentioned is the reason why there is a rise in industrial wage differentials in recent years. Yue, Li and Sicular (2010) divide industries into competitive and monopolistic sectors and use a Oaxaca-Blinder decomposition finding that the residual industry wage differential (holding worker characteristics constant) is "unreasonably large" in terms of what might be attributable to unobserved worker characteristics. They conclude that the high wages in these industries is attributable in large part to rent sharing.

Other recent research addresses the issue of growing urban wage inequality but does not focus in wage differentials by industry group. Ho, Dong, Bowles, and MacPhail (2002) note that privatization of rural industries in two provinces of China were associated with increased wage dispersion of workers according to their education, experience, and gender and that patterns were similar across different types of private ownership. Whalley and Xing (2010) come to somewhat different conclusions than do the authors of the two papers cited above. Their analysis, based on household surveys 
for the years 1995, 2002, and 2007, finds that the majority of the increase in urban wage inequality is attributable to the rise in the private sector's employment share, although rising inequality within the publicly-owned sector is also an important contributor.

Démurger, Li, and Yang analyze changes in public-private sector earnings differentials between 2002 and 2007 and report that although worker characteristics are increasingly important in explaining wage differentials, segmentation by ownership category remains an obstacle to workers in the lower-wage categories.

Methodology.Our econometric approach follows the literature in identifying industry wage differences and in attempting to account for them in identifying the effects of differences in worker characteristics across major industry groups. We use economy-wide industry aggregate data to estimate China's IWS and micro household survey data to obtain estimates of the contribution of worker characteristics to the industrial wage dispersion in China. Although we do not have matched worker-employer data, we can obtain industry and firm ownership data from the household information. However, we cannot proceed further than to obtain reduced-form estimates of the contributions of worker characteristics and employer ownership category to the IWS in China. Nevertheless, we believe that we achieve our goals: (i) to discover the degree to which the increasing dispersion of China's IWS can be explained in terms wage differentials that correspond to worker characteristics; (ii) to account for the contributions of privatization and market competition to the evolution of China's IWS.

Our basic model is

$$
\ln W_{i}=\beta_{0}+I_{i} \beta_{1}+X_{i} \beta_{2}
$$

where

$W_{i}$ is the ith person's main-job total earnings;

$I_{i}$ is a set of industry dummies indicating the industry of the main job; and $X_{i}$ is a set of worker characteristics including experience and dummy variables for highest educational attainment, gender, Chinese Communist Party membership, minority group status, and ownership type. 


\section{Empirical Results}

The estimation results for equation (1) are contained in table 3. Columns (1), (2), and (3) contain the estimation results for regressions that contain only the industry dummy variables. Columns (4), (5), and (6) report results including the worker control variables included in the vector $X$, and columns (7) and (8) report results comparable to those in (5) and (6) in which the dependent variable is hourly earnings. ${ }^{2}$ The regression results are not sensitive to whether total or hourly earnings is used as dependent variable, so we limit our discussion to the estimates based on total earnings, which is available for all survey years.

Contribution of Worker Characteristics. As illustrated in data based on industry aggregates, the dispersion of mean industrial wages has increased sharply. The standard deviation of the log-wage industry coefficients without worker characteristic controls doubled between 1988 and 1995, and doubled again by the year 2002. When worker controls are included, the standard deviation of the industry coefficients more than doubles between 1988 and 1995 and increases by 67 percent between 1995 and 2002 . The overall increase between 1988 and 2002 is four fold for the industry coefficients without worker controls and approximately 3.5 with worker controls.As a benchmark, we compare the standard deviation of the industry hourly wage coefficients with worker controls in the year 2002, 0.14, to that reported by Krueger and Summers (1984), 0.17 .

The last row of table shows the proportion of the dispersion of the IWS that can be accounted for in terms of worker characteristics, including firm-ownership sector. The proportion of the IWS dispersion that is accounted for by worker characteristics (including ownership sector) is [1-( $\mathrm{SD}(\mathrm{Yes}) \div \mathrm{SD}(\mathrm{No}))]$ and increases from 7 percent in 1988 to 12 percent in 1995 and 28 percent in the year 2002. When the dependent variable is hourly earnings, the proportion of the IWS dispersion accounted for by worker characteristics increases from 16 percent in 1995 to 30 percent in 2002. It is particularly noteworthy that most of the increased “explanatory power” of worker

\footnotetext{
${ }^{2}$ Work hours data are not available in CHIP 1988.
} 
characteristics comes from increasing returns to schooling as reflected in wages (holding industry group constant). Comparing column (6) with column (4), the estimated coefficient for professional school increases by 5-fold, that for upper middle school by a ratio of about 4.7 , and for university graduates by a ratio of about 4.0 . Thus the implicit annual rate of return to four years of college education increased from about $3.8 \%$ in 1988 to $12.7 \%$ in 2002 . There is a vast literature on increased returns to schooling in China as estimated from Mincer-type equations that documents similar increases in the return to schooling in China during the reform period, and we do not cite it here.

Other noteworthy changes in the coefficients of worker characteristics are an increase in the coefficient of the male gender dummy from 0.06 to 0.14 , a shift of the coefficient of the minority status dummy from -0.025 and -.058 in 1995 to 0.06 in 2002 . We note with particular interest that the coefficient of other-owned units (OOU) increased sharply between 1988 and 1995, but it decreased to virtually zero in 2002 . With log hourly earnings as the dependent variable, the coefficient of the OOU dummy falls from 0.37 in 1995 to -0.055 in 2002.

Contribution of Ownership Sector. As noted in our literature survey, the driving force behind increased (urban) income inequality in China appears to be the rising proportion of workers in the non-public sector. As illustrated clearly in figures 3 and 4 , the coefficient of variation of industry mean wages among OOU has been far greater than other ownership sectors, while the proportion of workers and staff employed in OOU has increased from negligible in 1980b to over 50 percent in 2008. At the same time, the degree of wage dispersion has risen in all sectors, although in proportionate terms, more so in state-owned and collectively-owned units. This observation, in conjunction with the virtual disappearance of the earnings advantage of employment in the non-public sector as evidenced by the worker characteristic coefficients in table 3 implies increasing integration of China’s industrial labor force. 


\section{Summary and Conclusion}

The hypothesis that increasing industry-wage dispersion in China has been

driven by the rise of competitive labor-market forces cannot be rejected on the basis of our empirical results. The rise in wage inequality can be explained as a result of increasing pay differentials according to observed worker characteristics particularly schooling. Moreover, since differential pay within the non-publicly owned sector has been much greater than within the state-owned sector, the rising proportion of workers in the private sector has increased overall wage inequality. The fact that the industrial wage pattern in China has come to match more closely the ranking of high- and low-wage industries across countries, a ranking that has been remarkably stable over time, implies that fundamental market forces are at work. Yet fascinating problems remain. (1) To what extent is the proportion of industry wage differentials unexplained by observed worker characteristics the result of pay for unobserved talents and abilities? (2) To what extent do high wage industries pay more simply because they are more profitable, and (3) how can rent sharing be separated from an efficiency-wage explanation of unexplained industry-wage differentials? Resolving these issues requires access to matched detailed employee and employer information which is not yet available. 
References

Chen, Zhao, Lu, Ming, Wan, Guanghua, 2009. Inter-Industry Wage Differentials: An Increasingly Important Contributor to Urban China Income Inequality. Fukino Project Discussion Paper Series. No. 016.

http://www.google.com/search?q=fukino\%20project\%20discussion\%20paper \%20series\%20No.\%20016\&ie=utf-8\&oe=utf-8\&aq=t\&rls=org.mozilla:en-US:

Dickens, William T., Katz, Lawrence F., 1987. Interindustry Wage Differences and Industry Characteristics, in K. Lang and J. S. Leonard, (eds.), Unemployment and the Structure of Labor Markets. Oxford, Basil Blackwell, 48-89. NBER Working Paper Series WP No. 2014. Cambridge, MA 02138, 1986.

Genre, Véronique, Kohn, Karsten, Momferatou, Daphne, 2009. Understanding Inter-Industry Wage Structures in the Euro Area. European Central Bank Working Paper Series No. 1022. Frankfurt am Main, Germany. http://www.ecb.int/pub/pdf/scpwps/ecbwp1022.pdf

Gustafsson, Bjorn, Li, Shi, 2001. The Anatomy of Rising Earnings Inequality in Urban China. Journal of Comparative Economics 29, 118-135.

Ho, Samuel P. S., Dong, Xiao-Yuan, Bowles, Paul, MacPhail, Fiona, 2002. Privatization and enterprise Wage Structures During Transition: Evidence from Rural Industry in China. Economics of Transition 10, 659-688.

Krueger, A. B., Summers, L. H., 1987. Reflections on the Inter-Industry Wage Structure, in K. Lang and J. S. Leonard, (eds.), Unemployment and the Structure of Labor Markets. Oxford, Basil Blackwell, 17-47. NBER Working Paper Series WP No. 1968. Cambridge, MA 02138, 1986.

Krueger, A. B., Summers, L. H., 1988. Efficiency Wages and the inter-Industry Wage Structure. Econometrica 56, 259-293.

Reder, Melvin W., 1962. Wage Differentials: Theory and Measurement. Aspects of Labor Economics. Princeton University Press for the Universities-National Bureau of Economic Research, 257-318. http://www.nber.org/books/univ62-2.

Rosen, Sherwin, 1986. The Theory of Equalizing Differences.HandbookofLaborEconomics. Handbooks in Economics series, no. 5. Amsterdam: North-Holland, vol.1, 641-92. 
Slichter, Sumner, 1950. Notes on the Structure of Wages. Review of Economics and Statistics 32, 80-91.

Whalley, John, Xing, Chunbing, 2010. The Regional Distribution of Skill Premia in Urban China. NBER Working Paper No. 16575.

Yang, Juan, Démurger, Sylvie, Li, Shi, 2010. Earnings Differentials Between the Public and the Private Sectors in China: Explaining Changing Trends for Urban Locals in the 2000s. GATE

http://papers.ssrn.com/sol3/papers.cfm?abstract_id=1731548 
Table 1

Rank Correlation of Industry Average Wages

With the year 2008 (for selected years)

\begin{tabular}{|l|l|l|l|}
\hline \multicolumn{3}{|l|}{ China } & U.S. \\
\hline Year & $\begin{array}{l}\text { Rank Correlation } \\
\text { With Agriculture, } \\
\text { Hunting, Forestry, } \\
\text { and Fishing }\end{array}$ & $\begin{array}{l}\text { Rank Correlation } \\
\text { Without Agriculture, } \\
\text { Hunting, Forestry, and } \\
\text { Fishing }\end{array}$ & $\begin{array}{l}\text { Rank Correlation } \\
\text { Without Agriculture, } \\
\text { Hunting, Forestry, and } \\
\text { Fishing }\end{array}$ \\
\hline 1978 & 0.4965 & 0.3455 & 0.9091 \\
\hline 1980 & 0.4685 & 0.3091 & 0.9021 \\
\hline 1985 & 0.4056 & 0.2273 & 0.8951 \\
\hline 1988 & 0.4755 & 0.3182 & 0.9231 \\
\hline 1991 & 0.4476 & 0.2818 & 0.9231 \\
\hline 1992 & 0.6573 & 0.5545 & 0.9231 \\
\hline 1993 & 0.5245 & 0.3818 & 0.9231 \\
\hline 1994 & 0.7133 & 0.6273 & 0.9161 \\
\hline 1997 & 0.8392 & 0.7909 & 0.9161 \\
\hline 2000 & 0.7063 & 0.6182 & 0.9580 \\
\hline 2003 & 0.8042 & 0.7455 & 0.9650 \\
\hline 2006 & 0.9580 & 0.9455 & 0.9650 \\
\hline 2008 & 1 & 1 & 1 \\
\hline
\end{tabular}


Table 2

Correlation of Average Industry Wage

With China (for selected years)

\begin{tabular}{|c|c|c|c|c|c|}
\hline Country & $\begin{array}{c}\text { With } \\
\text { China_197 } \\
8\end{array}$ & $\begin{array}{c}\text { With } \\
\text { China_198 } \\
0\end{array}$ & $\begin{array}{c}\text { With } \\
\text { China_200 } \\
7\end{array}$ & $\begin{array}{c}\text { With } \\
\text { China_200 } \\
8\end{array}$ & $\begin{array}{c}\text { Number } \\
\text { of } \\
\text { Industrie } \\
\mathrm{s}\end{array}$ \\
\hline Average & 0.3252 & 0.3071 & 0.6385 & 0.6352 & \\
\hline Australia_2004 & 0.4091 & 0.4436 & 0.4427 & 0.4624 & 10 \\
\hline Australia_2006 & 0.3411 & 0.4037 & 0.4082 & 0.4130 & 10 \\
\hline Canada_2007 & 0.8530 & 0.8989 & 0.0787 & 0.0710 & 10 \\
\hline Canada_2008 & 0.8514 & 0.8844 & 0.0992 & 0.0967 & 10 \\
\hline Denmark_2006 & 0.3957 & 0.3962 & 0.6084 & 0.6242 & 9 \\
\hline Denmark_2007 & 0.3552 & 0.3389 & 0.6869 & 0.7019 & 9 \\
\hline France_2001 & 0.2963 & 0.2761 & 0.7903 & 0.7889 & 10 \\
\hline France_2002 & 0.2634 & 0.2492 & 0.7697 & 0.7746 & 10 \\
\hline Germany_20007 & 0.2330 & 0.2246 & 0.7440 & 0.7353 & 9 \\
\hline Germany_2008 & 0.2380 & 0.2302 & 0.7486 & 0.7409 & 9 \\
\hline Japan_2007 & 0.3895 & 0.3493 & 0.5028 & 0.4768 & 7 \\
\hline Japan_2008 & 0.3894 & 0.3517 & 0.5008 & 0.4723 & 7 \\
\hline Korea_2007 & 0.4897 & 0.4471 & 0.7785 & 0.7643 & 9 \\
\hline Korea_2008 & 0.4590 & 0.4046 & 0.6984 & 0.6853 & 9 \\
\hline Netherlands_200 & 0.1372 & 0.2028 & 0.4707 & 0.4849 & 10 \\
\hline Netherlands_200 & 0.1316 & 0.1957 & 0.4752 & 0.4914 & 10 \\
\hline Portugal_2007 & 0.2161 & 0.1132 & 0.8721 & 0.8559 & 9 \\
\hline Portugal_2008 & 0.2432 & 0.1400 & 0.8688 & 0.8522 & 9 \\
\hline Spain_2007 & 0.2091 & 0.1626 & 0.8977 & 0.8866 & 9 \\
\hline Spain_2008 & 0.2124 & 0.1641 & 0.9049 & 0.8953 & 9 \\
\hline Switzerland_2006 & -0.0875 & 0.1633 & 0.8144 & 0.8086 & 10 \\
\hline Switzerland_2008 & -0.1009 & 0.1819 & 0.8169 & 0.8128 & 10 \\
\hline Taiwan_2007 & 0.6152 & 0.5838 & 0.6783 & 0.6488 & 8 \\
\hline Taiwan_2008 & 0.5831 & 0.5540 & 0.6928 & 0.6620 & 8 \\
\hline UK_2006 & 0.1846 & 0.1840 & 0.6019 & 0.6300 & 10 \\
\hline UK_2007 & 0.1464 & 0.1313 & 0.6489 & 0.6781 & 10 \\
\hline
\end{tabular}


Table 3 Log Wage Regressions: Household Data

\begin{tabular}{|c|c|c|c|c|c|c|c|c|c|}
\hline & (1) & (2) & (3) & (4) & (5) & (6) & (7) & (8) & (9) \\
\hline $\begin{array}{l}\text { Survey Year } \\
\text { Dependent Variable }\end{array}$ & $\begin{array}{c}1988 \\
\text { Earnings }\end{array}$ & $\begin{array}{c}1995 \\
\text { Earnings }\end{array}$ & $\begin{array}{c}2002 \\
\text { Earnings }\end{array}$ & $\begin{array}{c}1988 \\
\text { Earnings }\end{array}$ & $\begin{array}{c}1995 \\
\text { Earnings }\end{array}$ & $\begin{array}{c}2002 \\
\text { Earnings }\end{array}$ & $\begin{array}{c}1995 \\
\text { Hourly }\end{array}$ & $\begin{array}{c}2002 \\
\text { Hourly }\end{array}$ & $\begin{array}{l}K \& S \\
1984 \\
\end{array}$ \\
\hline Mining and Quarry & 0.03 & 0.02 & 0.01 & 0.009 & -0.02 & -0.04 & -0.005 & -0.01 & .26 \\
\hline Manufacturing & -0.02 & -0.09 & 0.01 & -0.003 & -0.02 & -0.03 & -0.03 & -0.02 & .08 \\
\hline Public Utilities & & & $0.38^{* * *}$ & & & $0.27^{* * *}$ & & $0.30^{* * *}$ & .29 \\
\hline Construction & 0.039 & -0.07 & 0.16 & 0.04 & -0.04 & 0.058 & -0.06 & 0.05 & .15 \\
\hline Trade, Hotels, Restrnts & 0.02 & $-0.16^{* * *}$ & -0.16 & 0.06 & -0.07 & -0.15 & -0.08 & $-0.18^{*}$ & .12 \\
\hline Transp.Stor.Communic. & $0.12^{* * *}$ & 0.07 & $0.25^{* *}$ & $0.10^{* * *}$ & 0.11 & $0.19^{* *}$ & 0.10 & $0.17^{*}$ & .17 \\
\hline Financial Intermed. & 0.02 & 0.09 & $0.38^{* * *}$ & 0.03 & $0.23^{* * *}$ & $0.22^{* *}$ & $0.25^{* * *}$ & $0.22^{* *}$ & .08 \\
\hline Real Estate & -0.04 & -0.03 & $0.38^{* * *}$ & -0.03 & 0.04 & $0.25^{* *}$ & 0.021 & $0.26^{* *}$ & \\
\hline Public Admin \& Defense & 0.07 & 0.09 & $0.33^{* *}$ & -0.005 & 0.02 & 0.09 & 0.01 & 0.06 & \\
\hline Education & 0.06 & $0.15^{* *}$ & $0.22^{*}$ & -0.04 & 0.06 & 0.10 & 0.08 & 0.19 & -.19 \\
\hline Health \& Social Work & 0.04 & $0.13^{*}$ & -0.13 & -0.002 & $0.11^{*}$ & -0.12 & 0.09 & -0.13 & -.20 \\
\hline Primary School & & & & $0.069 * *$ & 0.14 & $0.49 * *$ & 0.20 & 0.10 & \\
\hline Lower Middle & & & & $0.12 * *$ & $0.23 *$ & $0.71 * * *$ & $0.31 * *$ & $0.43^{*}$ & \\
\hline Professional School & & & & $0.19 * * *$ & $0.43 * * *$ & $0.99 * * *$ & $0.53 * * *$ & $0.75^{* * *}$ & \\
\hline Upper Middle School & & & & $0.20 * * *$ & $0.34 * * *$ & $0.93 * * *$ & $0.44 * * *$ & $0.67 * * *$ & \\
\hline Technical College & & & & $0.23 * * *$ & $0.55^{* * *}$ & $1.19 * * *$ & $0.66 * * *$ & $0.94 * * *$ & \\
\hline University Graduate & & & & $0.35 * * *$ & $0.61 * * *$ & $1.41 * * *$ & $0.73 * * *$ & $1.16 * * *$ & \\
\hline Experience (Age-Schooling) & & & & $0.034^{* * *}$ & $0.048 * * *$ & $0.025 * * *$ & $0.049 * * *$ & $0.022^{* * *}$ & \\
\hline Experience $^{2}\left(\div 10^{3}\right)$ & & & & $-0.48 * * *$ & $-0.71 * * *$ & $-0.25 * * *$ & $-0.70 * * *$ & $-0.16 * *$ & \\
\hline Male & & & & $0.060 * * *$ & $0.11 * * *$ & $0.14^{* * *}$ & $0.091^{* * *}$ & $0.093 * * *$ & \\
\hline Communist Party & & & & $0.067 * * *$ & $0.11 * * *$ & $0.089 * * *$ & $0.11 * * *$ & $0.085 * * *$ & \\
\hline Minority & & & & -0.025 & $-0.058 *$ & 0.06 & $-0.10 * * *$ & 0.090* & \\
\hline Coop Owned Unit & & & & $-0.075 * * *$ & $-0.21 * * *$ & $-0.18 * * *$ & $-0.22 * * *$ & $-0.19 * * *$ & \\
\hline Other Owned Unit & & & & $0.29 * * *$ & $0.48 * * *$ & 0.013 & $0.37 * * *$ & $-0.055^{* * *}$ & \\
\hline Constant & $5.04 * * *$ & $8.53 * * *$ & $9.04 * * *$ & $4.39 * * *$ & $7.48 * * *$ & $7.67 * * *$ & $-0.30 * *$ & 0.32 & \\
\hline $\mathrm{N}$ & 5704 & 6872 & 5660 & 5704 & 6872 & 5660 & 6872 & 5660 & \\
\hline $\mathrm{R}^{2}$ & 0.017 & 0.018 & 0.061 & 0.25 & 0.21 & 0.19 & 0.196 & 0.189 & \\
\hline StdDev of IndCoeff & 0.05 & 0.10 & 0.20 & 0.043 & 0.09 & 0.15 & 0.10 & 0.16 & \\
\hline $\mathrm{SD}(\mathrm{Yes}) \div \mathrm{SD}(\mathrm{No})$ (note 5 ) & & & & 0.93 & 0.88 & 0.72 & 0.84 & 0.70 & \\
\hline
\end{tabular}

Notes:

1.The dependent variable is log monthlyearnings in columns 1 through 6 and monthly earnings divided by hours worked in columns 7 and 8 .

2. Data come from China Household Income Project (CHIP) surveys conducted in.......Column 9 is from Krueger and Summers (198_).

Samples include respondents who reported themselves to be working or employed, including self-employed. Farmers are excluded.

3. Omitted dummy variables are (a) schooling level less than primary or illiterate; ownership is State; Omitted schooling level is less than primary and iliiterate; omitted ownership is SOE.

4. Significance levels are $* * * \mathrm{p}<0.01, * * \mathrm{p}<0.05, * \mathrm{p}<0.1$

5. The standard deviation of the industry coefficients with worker characteristics included divided by the standard deviation without worker characteristics. Proportion of IWS dispersion accounted for by worker characteristics is $[1-(\mathrm{SD}(\mathrm{Yes}) \div \mathrm{SD}(\mathrm{No}))]$ 
Figure 1

Coefficient of Variation of Industry Average Wage Across Countries

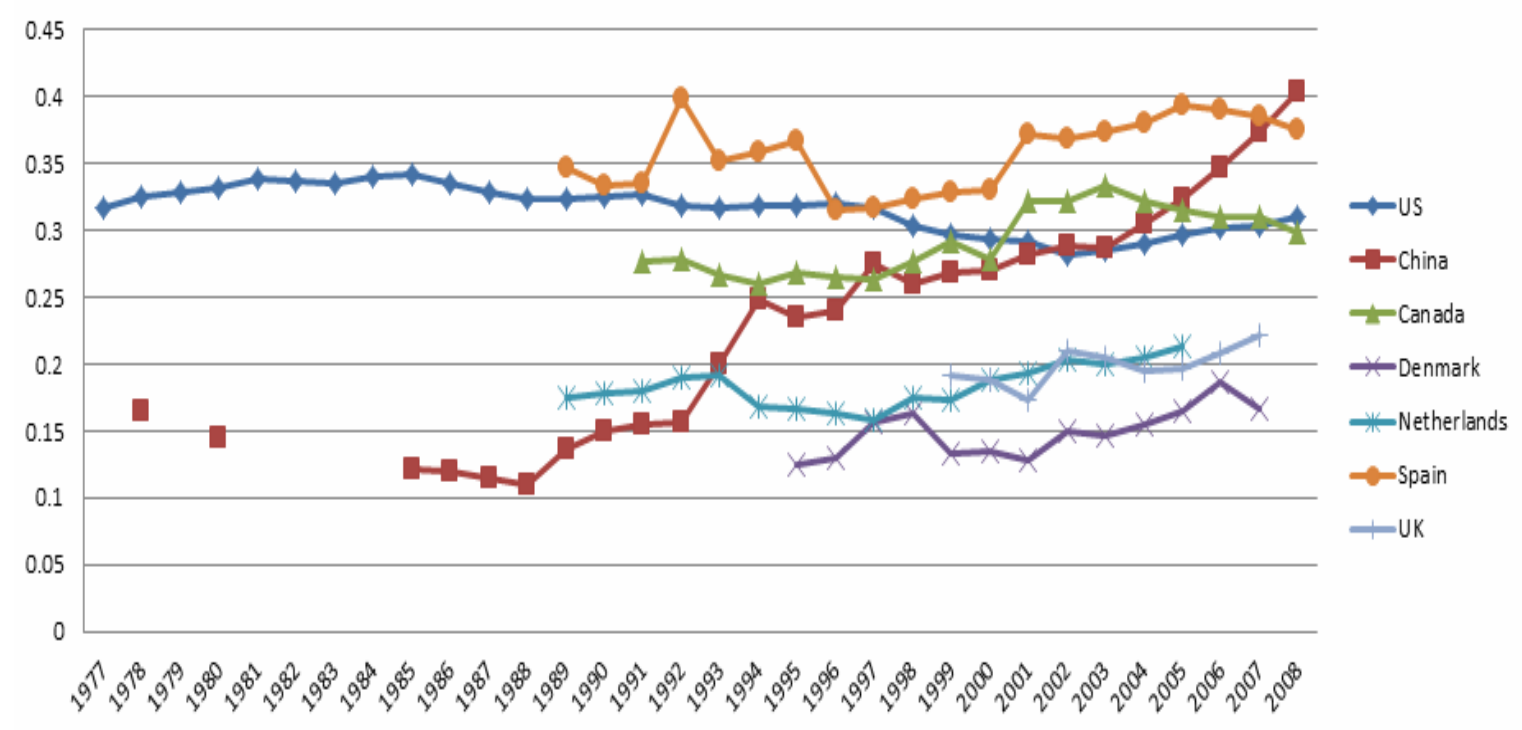


Figure 2. Average Correlation Coefficient of Industrial Mean Wages in China with 13 Developed Capitalist Countries

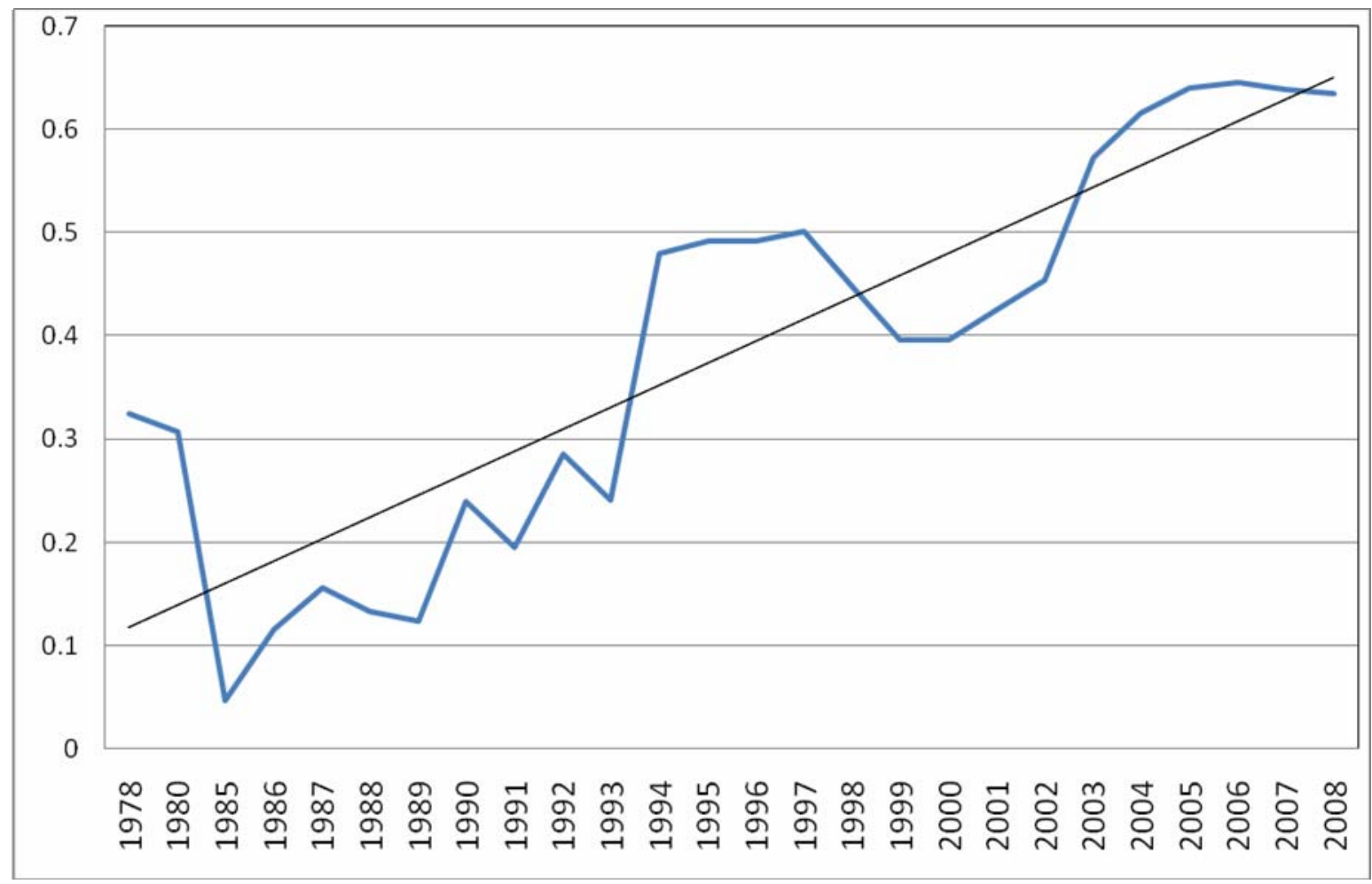


Figure 3. Coefficient of Variation, Industry Mean Wages by Ownership

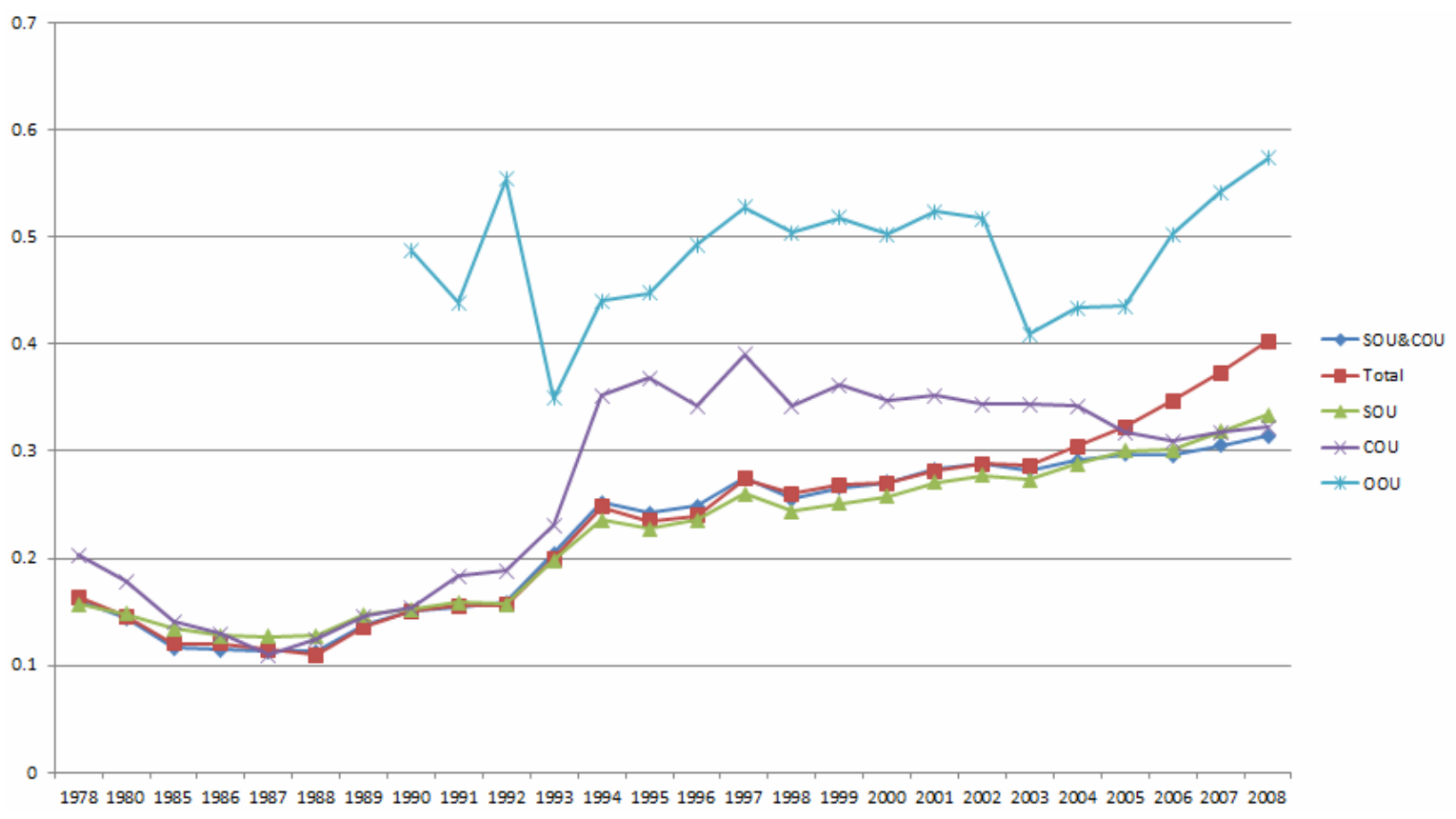


Figure 4. Proportion of Workers and Staff by Ownership Sector

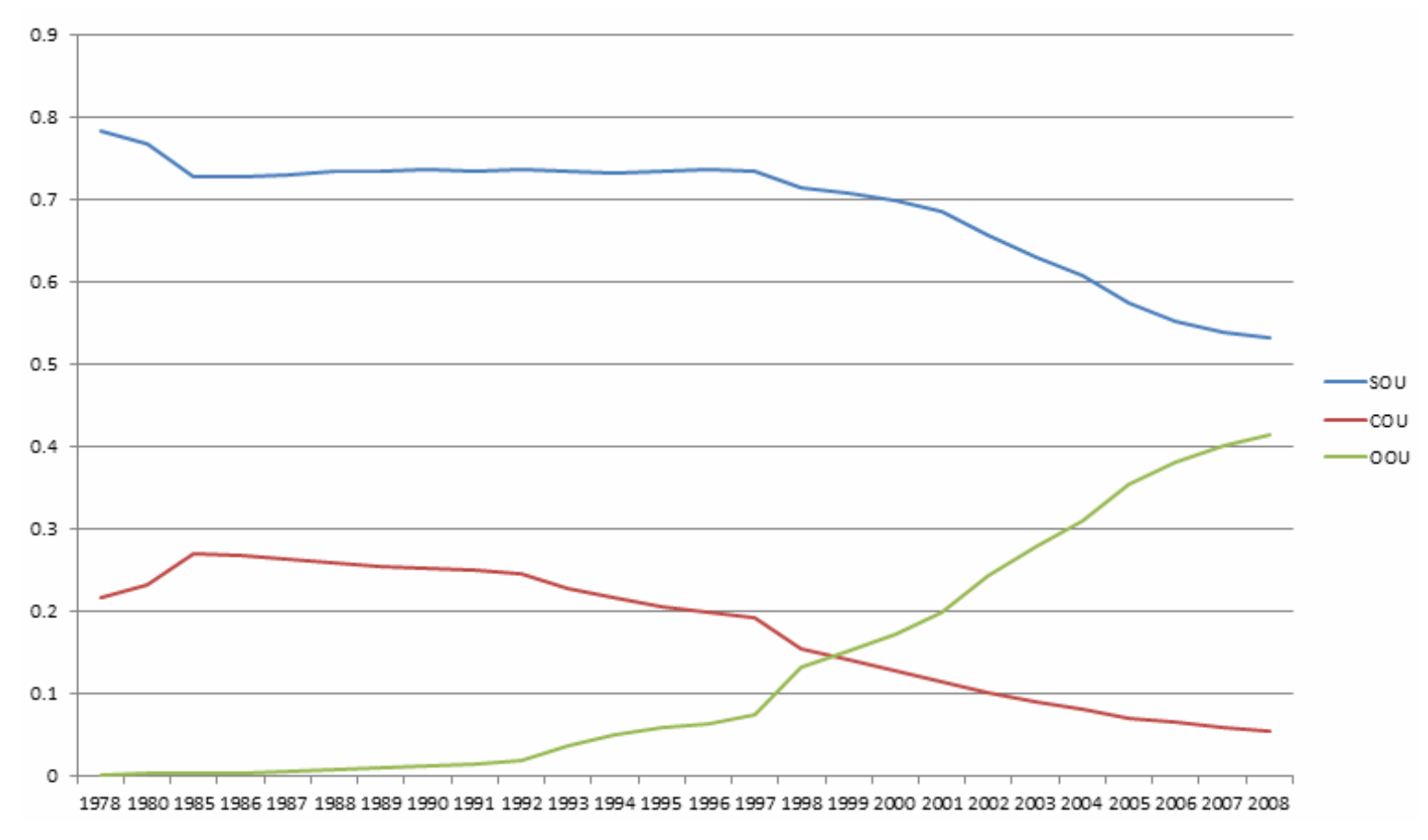

